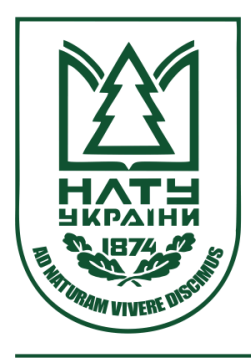

Науковий вісник НлТУ України Scientific Bulletin of UNFU

https://nv.nltu.edu.ua

https://doi.org/10.15421/40280609

$@ \bowtie$ Correspondence author

Article received 21.06.2018 p.

Article accepted 25.06.2018 p.

A. V. Kodzhebash

УДК 712.4-047.44(477.44)

В. П. Шлапак, А. В. Коджебаш, І. В. Козаченко, М. І. Парубок, С. А. Масловата

Уманський національний університет садівництва, м. Умань, Україна

\title{
ОЦІНЮВАННЯ СУЧАСНОГО СТАНУ ПАРКУ СЕЛА ІВАНІВКА УМАНСЬКОГО РАЙОНУ ТА ПРОЕКТ ЙОГО РЕКОНСТРУКЦІЇ
}

\begin{abstract}
Встановлено, що насадження парку потребують покращення, оскільки деревні насадження одноманітні, значна кількість дерев представлена гіркокаштаном звичайним (Aesculus hippocastanum L.), що уражується мінуючою міллю, інші дерева також ослаблі, трапляється омела. За межами парку простежується велика кількість омели. Мережа доріжок розвинена слабо, малі архітектурні форми представлені у незначній кількості, на території парку присутні аварійні дерева. Розроблено проект реконструкції парку, який охоплює консервацію дупел, санітарне обрізування та рубання дерев і кущів, формування кущового ярусу у структурі насадження, розширення дорожньо-стежкової мережі. Запроектовано створення кількох рокаріїв 3 використанням листяних і хвойних кущів, різних трав'яних багаторічників, зокрема й цибулькових. Підібрано асортимент для рокаріїв, щоб він виглядав декоративним протягом року. Заплановано кілька групових посадок із хвойних рослин та солітерів - ялини колючої (Picea abies (L.) H. Karst.) та сосни звичайної (Pinus sylvestris L.). Запропоновано встановити елементи благоустрою, такі як: садові лавки, альтанка, ліхтарі, урни для сміття. Навколо альтанки запропоновано створення квітників постійного квітування - міксбордерів. В озелененні використано елементи топіарного мистецтва, а саме: композиції зі стриженого самшиту вічнозеленого (Buxus sempervirens L.) у вигляді куль, а також елементи фітопластики. Композиції 3 куль самшиту вічнозеленого урізноманітнюємо багаторічником - гостою подорожниковидною (Hosta plantaginea (Lam.) Asch.). Рекомендовано частину парку реконструювати за типом регулярного планування, а частину - за типом пейзажного.
\end{abstract}

Ключові слова: паркові насадження; генеральний план; баланс території; квітники; доріжки; дерева.

Вступ. У сучасному світі дедалі поширенішим стає озеленення населених міст. На жаль, створення нових та реконструкція наявних парків і скверів часто проходить повз малі села. Не винятком $\epsilon$ село Іванівка Уманського р-ну, що в Черкаській обл. Тут постає нагальна проблема виконання робіт з реконструкції парку. Адже парк перебуває у занедбаному стані, внаслідок чого втрачена естетична, а також і функціональна цінність. Він переважно використовується лише як транзитний, а не для відпочинку.

Мета дослідження - проаналізувати основні проблеми та недоліки об'єкта; розробити проект реконструкції парку в с. Іванівка Уманського р-ну, що сприятиме покращенню його фітоценотичної структури та естетичної цінності.

Матеріали та методика дослідження. Матеріалом дослідження $є$ насадження парку та його архітектурнопланувальне рішення. Під час розроблення проекту керувалися загальноприйнятими методиками із планування та реконструкції об'єктів озеленення (Dudyn, 2016; Kucheryavyy, 2005; Shlapak \& Yegorov 2017). Українські назви вказували відповідно до визначника рослин
(Dobrochaieva et al., 1987), латинські назви - згідно 3 міжнародною системою (The Plant List, 2018). Під час оцінювання сучасного стану керувалися методикою Ю. О. Клименка та С. І. Кузніцова (Klimenko \& Kuznetsov, 2014). Проводили по деревну таксацію насадження. Висоту дерев вимірювали висотоміром, діаметр стовбура дерев на висоті 1,3 м - за допомогою мірної вилки. Під час оцінювання фітосанітарного стану насаджень користувалися методикою визначення ступеня ураження омелою (Shlapak, Muzyka \& Vitenko, 2011). Належність до типу ландшафту встановлювали за методичною класифікацією Л. І. Рубцова (Rubtsov \& Laptev, 1971).

Результати дослідження та їх обговорення. У 1956 р. в селі Іванівка було відкрито сільський клуб, а в 1957-1958 рр. висаджено парк біля нього, де в 1966 р. встановлено погруддя Т. Г. Шевченку. 3 північно-західної сторони від парку проходить вул. Центральна (до декомунізації - вул. Леніна), 3 північно-східної - вул. Миру (колишня вул. Калініна), 3 південно-східної вул. Спортивна (раніше вул. Горького). Парк межує 3 приватною забудовою, школою та сільською радою.

\section{Інформація про авторів:}

Шлапак Володимир Петрович, д-р с.-г. наук, професор, кафедра лісового господарства. Email: shlapakwp@gmail.com Коджебаш Анастасія Вадимівна, аспірант, кафедра лісового господарства. Email: anastasiia.vadumivna@gmail.com Козаченко Ірина Володимирівна, канд. с.-г. наук, доцент, кафедра лісового господарства. Email: Kozachenko_irina79@ukr.net Парубок Маргарита Іванівна, канд. біол. наук, доцент, кафедра садово-паркового господарства. Email: m.parubok69@gmail.com Масловата Світлана Андріївна, канд. с.-г. наук, викладач, кафедра лісового господарства. Email: svetlana_maslovataya@meta.ua Цитування за ДСту: Шлапак В. П., Коджебаш А. В., Козаченко І. В., Парубок М. І., Масловата С. А. Оцінювання сучасного стану парку села Іванівка Уманського району та проект його реконструкції. Науковий вісник НЛтУ України. 2018, т. 28, № 6. С. 47-51.

Citation APA: Shlapak, V. P., Kodzhebash, A. V., Kozachenko, I. V., Parubok, M. I., \& Maslovata, S. A. (2018). Assessment of current situation of the park in Ivanivka village of Uman district and the project of its reconstruction. Scientific Bulletin of UNFU, 28(6), 4751. https://doi.org/10.15421/40280609 
3'ясовано, що видовий склад насадження парку (табл. 1) бідний, одноманітний. На території парку зростає 316 дерев і 5 кущів, насадження переважно одновікове. Деревна флора представлена 16 видами (14 видів дерев та 2 кущів), що входять до 12 родин (Kodzhebash, 2017).

Табл. 1. Видовий склад насадження парку в с. Іванівка

\begin{tabular}{|c|c|c|c|c|c|}
\hline \multirow[b]{2}{*}{$\begin{array}{l}\text { № } \\
\text { 3/ח }\end{array}$} & \multirow[b]{2}{*}{ Вид } & \multirow[b]{2}{*}{$\begin{array}{l}\text { Кіль- } \\
\text { кість, } \\
\text { шт. }\end{array}$} & \multicolumn{3}{|c|}{ Середні показники } \\
\hline & & & $\begin{array}{l}\text { висота, } \\
\text { м }\end{array}$ & $\begin{array}{c}\text { діаметр } \\
\text { стовбура, } \\
\text { см }\end{array}$ & $\begin{array}{c}\text { діаметр } \\
\text { крони, } \\
\text { м }\end{array}$ \\
\hline 1 & Tilia cors & 60 & 13,0 & $31,5^{ \pm 10, / 2}$ & $5,7^{ \pm 1,68}$ \\
\hline 2 & $\begin{array}{l}b i- \\
\text { H. Ka }\end{array}$ & 9 & $3,5^{ \pm 1,35}$ & $42,0^{ \pm 9,05}$ & $6,1^{ \pm 1,31}$ \\
\hline 3 & Thuja occibentalis L. & 21 & $8,7^{ \pm}$ & $20,1^{ \pm 6}$ & $3,8^{ \pm}$ \\
\hline 4 & Gleditsia triacanthos L. & 2 & $20,0^{ \pm 1,4}$ & $47,5^{ \pm 0,7}$ & $9,8^{ \pm 1,}$ \\
\hline 5 & Juglans regia L. & 1 & 5 & 16,5 & 4,5 \\
\hline 6 & igra L. & 1 & 13,5 & 36,5 & 10 \\
\hline 7 & Moru & 1 & 7,0 & 10 & 3,5 \\
\hline 8 & is betulus L. & 5 & $11,6^{ \pm 3}$ & $22^{ \pm}$ & $6,2^{ \pm}$ \\
\hline 9 & doplatanus L. & 6 & $13,2^{ \pm 2,9}$ & $33,7^{ \pm 6}$ & $6,2^{ \pm 2}$ \\
\hline 10 & anoides L. & 67 & $14,1^{ \pm 2,8}$ & $35,9^{ \pm 10,6}$ & $6,5^{ \pm 2}$ \\
\hline 11 & $\begin{array}{l}\text { Aesculus hippocasta- } \\
\text { num L. }\end{array}$ & 120 & 9 & $27,7^{ \pm 7,1}$ & $4,9^{ \pm 1}$ \\
\hline 12 & ndula Roth & 20 & $12,4^{ \pm 3,2}$ & 29,9 & $4,2^{ \pm 1,}$ \\
\hline 13 & Ulmus leavis Pall. & 2 & $15,8^{ \pm 3,2}$ & $45,8^{ \pm 16,6}$ & $8,3^{ \pm 3,2}$ \\
\hline+ & Fraxinus excelsior $\mathrm{L}$. & 1 & 15,0 & 44,0 & 7,0 \\
\hline
\end{tabular}

Представлено горизонтальну структуру мікроасоціації насадження парку. За основу взято насадження в колі 3 радіусом 25 м, тобто площа ділянки дорівнює $490 \mathrm{~m}^{2}$ (рис. 1).

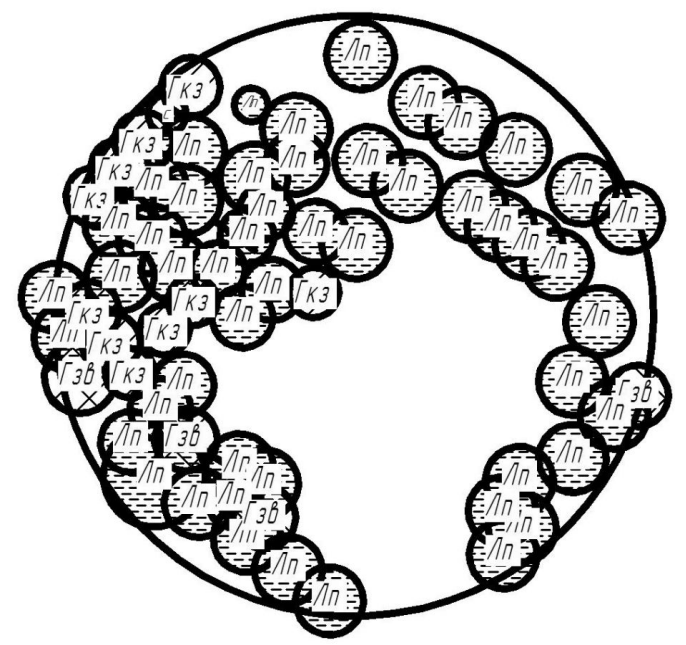

Рис. 1. Горизонтальна структура насадження: Гкз - гіркокаштан звичайний; Лп - липа серце листа; Гзв - граб звичайний

Розподіл переважаючих видів дерев відносно висоти стовбура наведено на рис. 2.

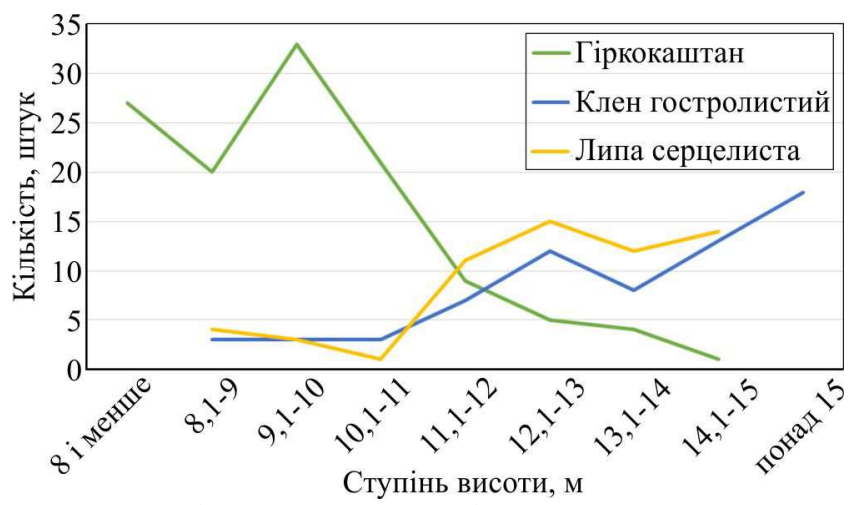

Рис. 2. Розподіл переважаючих видів дерев за висотою
3 графіка (див. рис. 2) видно, що найбільше дерев гіркокаштана звичайного з висотою у межах 9,1-10,0 м, також значна частка гіркокаштану не перевищує 8,0 м у висоту. Серед клена гостролистого переважають дерева 3 висотою стовбура понад 15,0 м, липи серцелистої $12,1-13,0 \mathrm{M}$.

Проведено розподіл переважаючих видів дерев відносно діаметра стовбура на висоті 1,3 м (рис. 3).

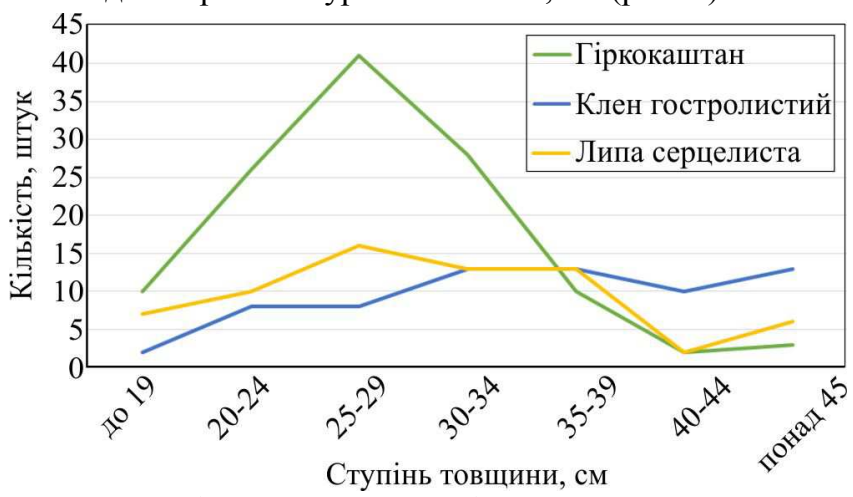

Рис. 3. Розподіл переважаючих видів дерев за ступенями товщини стовбура

3 рис. 3 видно, що переважає гіркокаштан звичайний 3 діаметром стовбура (на висоті 1,3 м) від 25 до 29 см. У клена гостролистого частіше трапляються дерева 3 діаметром 35-39 см, у липи серцелистої - 3039 см.

Пропозиції щодо покращення стану парку представлено на плані з проекту реконструкції (рис. 4).

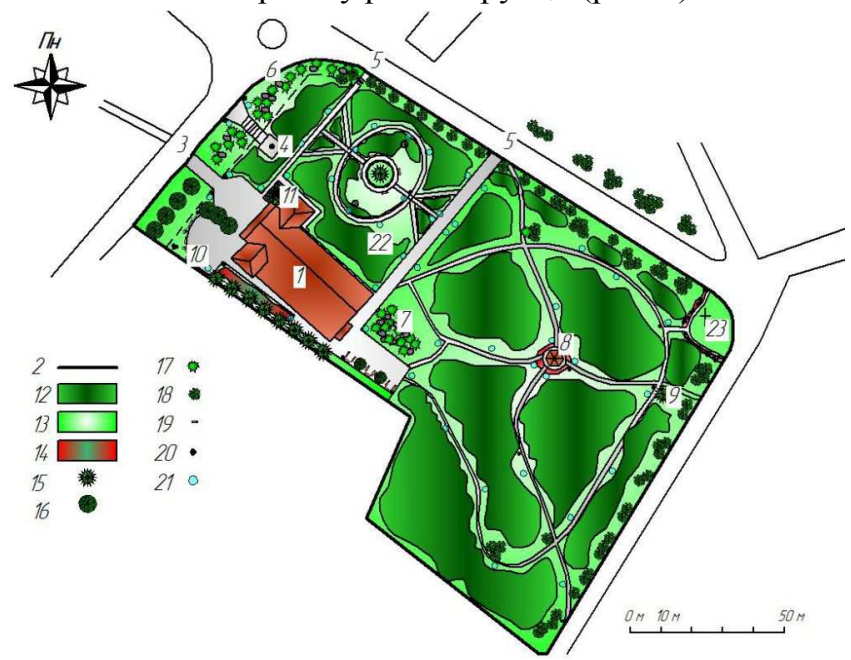

Рис. 4. Проект реконструкції парку: 1) Будинок культури; 2) межі парку; 3) головний вхід до парку; 4) пам'ятник Т. Г. Шевченку; 5) другорядний вхід; 6) рокарій при вході; 7) рокарій у центральній частині; 8) альтанка; 9) сосна звичайна 3 круговою лавкою навколо стовбура; 10) елемент фітопластики (група стриженого самшиту вічнозеленого); 11) композиція 3 хвойних рослин; 12) деревні насадження; 13) газон; 14) кизильник Даммера; 15) хвойне дерево; 16) листяне дерево; 17) хвойний кущ; 18) листяний кущ; 19) лавка; 20) урна для сміття; 21) ліхтар; 22) композиція з самшиту вічнозеленого та гости подорожниковидної; 23) дерев'яний хрест

Велика частка дерев перебуває у незадовільному стані, наявні аварійні дерева. 3 огляду на це потрібно здійснити санітарне обрізування та рубання дерев і кущів, а також консервування дупел. Також постає потреба у створенні нового ярусу, додавши кущові рослини: Forsythia suspense (Thunb.) Vahl, Philadelphus coronarius L., Spiraea $\times$ vanhouttei (Briot) Zabel, Juniperus $\times$ pfitzeri- 
ana (Späth) P. A. Schmidt. тощо. Оскільки у парку немає узлісся, пропонуємо створити вздовж дороги (від вул. Миру) групові посадки декоративних кущів: Berberis thunbergii D. C. 'Atropurpurea', Rosa robusta L., Syringa vulgaris L., Forsythia suspense (Thunb.) Vahl, Laburnum anagyroides Medic, Philadelphus coronarius L. тощо. Стежкова мережа $\epsilon$ слабо розвиненою, тому постає потреба у збільшенні ії розгалуження. Пропонуємо як покрівельний матеріал використати бетонну тротуарну плитку. Такий матеріал у наш час $є$ поширеним, має низку переваг порівняно $з$ асфальтовим. Зокрема $\epsilon$ дешевшим, досить естетичним та не виділяє шкідливих речовин.

У північній частині парку, біля входу, де $є$ природне підвищення рельєфу, плануємо створити рокарій. Під час його облаштування використати гранітний камінь $\mathrm{i}$ такі рослини:

- барбарис Тунберга - B. thunbergii D. C. 'Atropurpurea';

- яловець Пфітцеріана - Juniperus ×pfitzeriana (Späth) P. A. Schmidt;

- яловець Пфітцеріана - J.×pfitzeriana (Späth) P. A. Schmidt, 'Gold star';

- яловець горизонтальний - J. horizontalis Moench 'Wiltonii';

- яловець горизонтальний - J. horizontalis Moench 'Blue chip';

- очиток їдкий - Sedum acre L.;

- тюльпан гібридний - Tulipa $\times$ hybridum;

- айстра новобельгійська - Aster novae-belgiae var. novae-belgiae.

Рослини висаджуємо так, щоб ближче до дороги зростали лише трав'яні рослини. Кущі висаджуємо далі від узбіччя, щоб у разі нагортання снігу з дороги, вони не постраждали. Протяжність цього рокарію буде від головного входу, до входу з вул. Миру. Водночас ця композиція буде розміщуватися по обидві сторони від сходів, що ведуть до погруддя Т. Г. Шевченка. Ці посадки покращать не лише естетичний вигляд парку, а й села загалом, адже його буде видно ще з території загальноосвітньої школи та автобусної зупинки. Візуалізацію запропонованого рокарію наведено на рис. 5 .

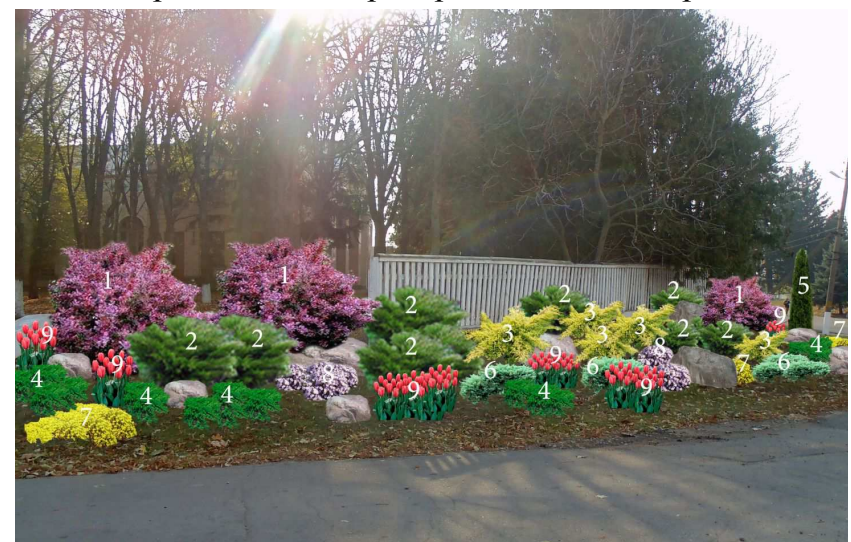

Рис. 5. Візуалізація проекту рокарію у північній частині парку с. Іванівка: 1) B. thunbergii D. C. 'Atropurpurea'; 2) J.×pfitzeriana (Späth) P. A. Schmidt; 3) J. ×pfitzeriana (Späth) P. A. Schmidt, 'Gold star'; 4) J. horizontalis Moench 'Wiltonii'; 5) Thuja occibentalis L. 'Holmstrup'; 6) J. horizontalis Moench 'Blue chip'; 7) S. acre L.; 8) A. novae-belgiae var. novae-belgiae; 9) T.×hybridum

3 двох боків від доріжки, що веде до погруддя Т. Г. Шевченка, запроектовано посадку Thuja occibentalis L. 'Holmstrup'.

Майданчику, що перед будівлею, надати чіткіші обриси, встановити лавки для відпочинку, розмістити квіткові композиції в контейнерах. Видалити Betula pendula Roth, що втратила естетичний вигляд (на цей час зрізана до половини стовбура) та має негативну декоративність. Позаду лавочок у кутку сформувати композицію із хвойних рослин, для якої використати J. scopulorum Sarg. 'Skyrocet' - 2 шт., T. occibentalis L. 'Globosa' - 1 шт., J. sabina L. 'Tamariscifolia' - 2 шт. Також пропонуємо використати такий сучасний засіб ландшафтного дизайну, як фітопластика. Він полягає у створенні рослинами візуального рельєфу завдяки стрижці рослин. Для цього використовуємо B. sempervirens L., що добре піддається формуванню. Запроектовано 4 таких композиції (рис. 6).

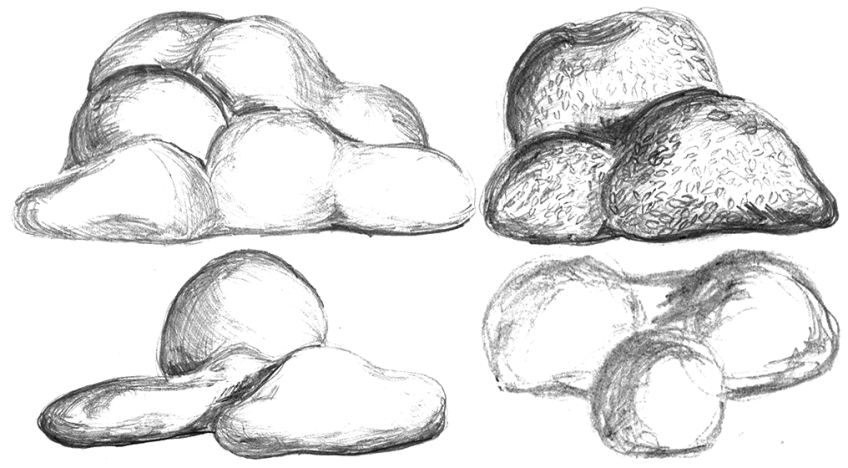

Рис. 6. Елементи фітопластики (стрижений B. sempervirens L.)

На ділянці, що поруч з головним входом до будинку культури, створити композицію з вічнозелених деревних рослин, таких як: J. scopulorum Sarg. 'Blue Arrow' 3 шт., J. sabina L. 'Tamariscifolia' - 7 шт., J. horizontalis Moench 'Blue Chip' - 45 шт., Thuja occibentalis L. 'Danica' -6 шт.

На північний схід від будинку культури, у насадженнях $з$ переважанням Tilia cordata Mill. заплановано створити ділянку з регулярним плануванням. На цій ділянці попередньо потрібно вирубати сухостій та $\mathrm{Aescu}$ lus hippocastanum L. у центральній частині ділянки, провести корчування пнів та планування території. Потім висадити Picea pungens Engelm., навколо сформувати стрижений бордюр $3 S$. japonica L. 'Little Princess', навколо облаштувати доріжку, встановити 4 лавки. Також на цій ділянці створити дві композиції з використанням $B$. sempervirens L., що сформований кулями та Hosta plantaginea (Lam.) Asch. (рис. 7). Ці рослини є оптимальними для створення такої композиції, адже добре будуть рости та зберігатимуть високу декоративність навіть у затіненні.

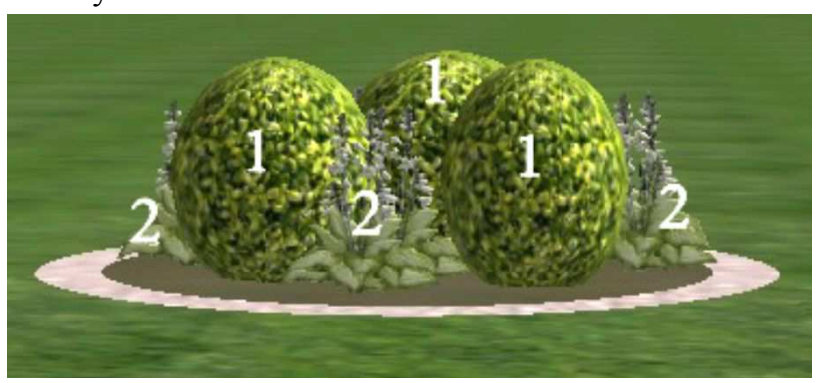

Рис. 7. Композиція зі самшиту вічнозеленого (1) та гости подорожниковидної (2)

На північний захід від будинку культури висаджено рядову посадку ялини звичайної. Щоб поліпшити декоративність земельної ділянки поруч $з$ цими хвойними деревами, пропонуємо висадити Cotoneaster Dammeri C. K. Schneid. Він є стійким та декоративним всі сезони, оскільки вічнозелений і має червоні ягоди, що довго залишаються на рослині. Для формування цієї куртини потрібно 280 рослин, за густоти посадки 4 шт./м². 
Дещо далі плануємо встановити садові лавки для відпочинку. Їх буде встановлено комплексами по 3 шт., між ними висадити Prunus cerasus L. 'Umbraculifera'. Для цього потрібно буде підготувати 2 посадкових місця, адже в цій частині парку асфальтоване покриття.
Наступна зона запланована у пейзажному стилі. Тут запроектовано альтанку, навколо якої пропонуємо створити міксбордер, тобто квітник безперервного квітування. Площа квітника становить $30 \mathrm{~m}^{2}$. Асортимент рослин для нього наведено у табл. 2.

Табл. 2. Асортимент рослин для міксбордеру

\begin{tabular}{|c|c|c|c|c|c|}
\hline \multirow{2}{*}{$\begin{array}{l}\text { № } \\
\text { 3/П }\end{array}$} & \multicolumn{2}{|r|}{ Назва } & \multirow{2}{*}{ Період квітування } & \multirow{2}{*}{ Колір } & \multirow{2}{*}{ Кілть, шт. } \\
\hline & Українська & Латинська & & & \\
\hline 1 & Вероніка вірменська & Veronica armena Boiss., \& A. Huet. & травень-червень & блакитний & 50 \\
\hline 2 & Гайлардія великоквіткова & $\begin{array}{c}\text { Gaillardia } \times \text { grandiflora Hort. ex } \\
\text { Van Houtte }\end{array}$ & червень-жовтень & жовто-червоний & 12 \\
\hline 3 & Злинка красива & Erigeron speciosus (Lindl.) DC. & червень-серпень & бузковий & 10 \\
\hline 4 & Півники бородаті сортові & Iris hybrida cultivars & травень & різні кольори & 40 \\
\hline 5 & Півонія молочноквіткова & Paeonia lactiflora Pall. & травень & рожевий, червоний & 9 \\
\hline 6 & Проліска дволиста & Scilla bifolia L. & березень-квітень & блакитний & 100 \\
\hline 7 & Стокротки багаторічні & Bellis perennis L. & квітень-пізня осінь & білий, рожевий & 200 \\
\hline 8 & Фіалка лісова & Viola reichenbachiana L. & квітень & блакитний & 75 \\
\hline 9 & Флокс шиловидний & Phlox subulata L. & липень-серпень & рожевий & 40 \\
\hline 10 & Госта подорожниковидна & Hosta plantaginea (Lam.) Asch. & $\begin{array}{c}\text { липень-серпень, декора- } \\
\text { тивна протягом усього ве- } \\
\text { гетаційного періоду }\end{array}$ & білий & 20 \\
\hline 11 & Хризантема садова & Chrysanthemum morifolium Ramat. & жовтень & Різні кольори & 12 \\
\hline
\end{tabular}

У цій зоні також проектують розширення мережі доріжок. Доріжки проходитимуть по колу, а також сполучатимуть такі елементи, як: альтанка, рокарій, що розміщений у південно-східній стороні від будівлі тощо. Також пропонуємо висадити Pinus sylvestris L., а навколо неї облаштувати кругову лавку для довготривалого відпочинку. На перетині деяких доріжок формуємо акценти у вигляді композицій $з$ декоративних кущів. Для цього висаджуємо як хвойні (представників роду Juniperus), так і декоративноквітучі кущі.

Центральний рокарій будемо створювати на невеликому підвищенні. Для цього попередньо потрібно розчистити і підготувати територію. Пропонуємо використати такий камінь, як граніт, оскільки він характерний для цієї місцевості. Для рокарію використовуємо такі рослини:

- яловець горизонтальний - Juniperus horisintalis 'Wiltonii';

- яловець горизонтальний - J. horisintalis 'Blue Chip';

- очиток їдкий - Sedum acre L.;

- тюльпан гібридний - Tulipa $\times$ hybridum;

- айстра новобельгійська - Aster novae-belgiae var. novae-belgiae;

- флокс шиловидний - Phlox subulata L;

- гайлардія великоквіткова - Gaillardia $\times$ grandiflora Hort. ex Van Houtte;

- шафран жовтий - Crocus flavus Weston;

- бересклет форчуна- Euonymus fortunei (Turcz.) Hand.-Mazz.;

- кизильник Даммера - Cotoneaster Dammeri C. K. Schneid.

У східній частині парку встановлено дерев'яний хрест, біля якого здійснюють освячення на Пасху. Пропонуємо біля хреста створити доріжку, а для підвищення декоративності з зовнішнього боку створити декоративні посадки 3 кущів та багаторічників. Для цього використовуємо: B. sempervirens L., F. ×intermedia 'Minigold', T. ×hybridum, різні види і сорти роду Iris L.

$\mathrm{У}$ парку потрібно встановити урни для сміття, у кількості 15 шт. Також рекомендуємо облаштування мережі освітлення. Згідно з проектом, баланс території наведено у табл. 3.

3 табл. 3 видно, що найбільша частка території припадає на зелені насадження - 81,3\%. За класифікацією Л. І. Рубцова, парк буде поділено на такі типи ландшафтів: парковий, регулярний та альпійський. Найбільшу частку займатиме парковий тип - $\left(11438 \mathrm{~m}^{2}\right)$ $63,5 \%$, а найменшу - альпійський 3,2 \% (570 м²).
Табл. 3. Баланс території парку с. Іванівка

\begin{tabular}{|c|c|c|c|}
\hline \multirow{2}{*}{$№$} & \multirow{2}{*}{ Найменування } & \multicolumn{2}{|c|}{ Площа } \\
\cline { 3 - 4 } & & $\mathrm{M}^{2}$ & $\%$ \\
\hline 1 & Зелені насадження & 14639 & 81,3 \\
\hline 2 & Доріжки та майданчики & 2303 & 12,8 \\
\hline 3 & Будівлі & 1026 & 5,7 \\
\hline 4 & Інше & 32 & 0,2 \\
\hline \multicolumn{2}{|r}{} \\
\hline
\end{tabular}

На північ від парку, через дорогу, у деревних насадженнях присутні дерева, що уражені омелою. Тому доцільно провести боротьбу з нею, щоб запобігти іiі розповсюдженню. Для візуального розширення парку, а також заради гармонійного поєднання 3 навколишнім середовищем, рекомендуємо на тій ділянці вздовж дороги висадити групові посадки декоративних кущів тих самим видів, що і на території парку.

\section{Перелік використаних джерел}

Dobrochaieva, D. N., Kotov, M. I., Prokudin, Yu. N., et al. (1987). Opredelitel vysshykh rastenii Ukrainy. Kyiv: Naukova dumka. 548 p. [In Russian].

Dudyn, R. B. (2016). Konservatsiia, restavratsiia ta rekonstruktsiia sadovo-parkovykh obiektiv. Lviv: Manuskrypt. 216 p. [In Ukrainian].

Klimenko, Yu. O., \& Kuznetsov, S. I. (2014). Kompleksna otsinka parkovih nasadzhen (metodichni pidhodi $i$ rekomendatsiyi) [Comprehensive evaluation of parkings (methodological approaches and recommendations)]. Kyiv. 66 p. [In Ukrainian].

Kodzhebash, A. V. (2017). Green planting park's of vilage Ivanivka. Proceedings of $X$ International scientific conference "Scientific thought transformation". Morrisville, Lulu Press., 34-38. [In Ukrainian].

Kucheryavyy, V. P. (2005). Ozelenennya naselenykh mists. Lviv: Svit. 455 p. [In Ukrainian].

Rubtsov, L. I., \& Laptev, A. A. (1971). Spravochnik po zelenomu stroitelstvu Rubtsov. Kyiv: Stroitel, 341 p. [In Russian].

Shlapak, V. P., \& Yegorov, Yu. I. (2017). Spatial Environment Landscape Architecture Analysis of the I. D. Chernyakhovsky Park in Uman and Drafting Reconstruction. Scientific Bulletin of UNFU, 27(4), 15-20. https://doi.org/10.15421/40270402

Shlapak, V. P., Muzyka, G. I., \& Vitenko, V. A. (2011). Metodyka vyznachennia stupenya poshkodzhennya derevnykh roslyn Viscum album L. (omeloiu biloiu) ta ii praktychne zastosuvannia. Landshaftna arkhitektura $v$ botanichnykh sadakh $i$ dendroparkakh: mater. III mezhdunar. konf., 8-11 iyunia, (pp. 414-420). Kyiv: NBS im. N. N. Hryshka. [In Ukrainian].

The Plant List. (2018). Retrieved from: http://www.theplantlist.org/. 


\section{ОЦЕНКА НЫНЕШНЕГО СОСТОЯНИЯ ПАРКА С. ИВАНОВКА УМАНСКОГО РАЙОНА И ПРОЕКТ ЕГО РЕКОНСТРУКЦИИ}

Определено, что насаждения парка требуют улучшения, так как древесные насаждения однообразные, значительное количество деревьев представлено конским каштаном обыкновенным, который поражается каштановой минирующей молью, другие деревья также ослаблены, встречается омела. За пределами парка прослеживается большое количество омелы. Сеть дорожек развита слабо, малые архитектурные формы представлены в незначительном количестве, на территории парка находятся аварийные деревья. Разработан проект реконструкции парка, который включает консервацию дупел, санитарную обрезку и рубку деревьев и кустарников, формирование кустарникового яруса в структуре насаждения, расширение дорожно-тропиночной сети. Запроектировано создание нескольких рокариев с использованием лиственных и хвойных кустарников, различных травянистых многолетников, в том числе и луковичных. Подобран ассортимент для рокариев, чтобы он выглядел декоративно на протяжении года. Запланировано несколько групповых посадок хвойных растений и одиночных - ели колючей и сосны обыкновенной. Предлагается установить такие элементы благоустройства, как: садовые скамейки, беседка, фонари, урны для мусора. Вокруг беседки предложено создание цветников постоянного цветения - миксбордеров. В озеленении используем элементы топиарного искусства, а именно: композиции из стриженого самшита в виде шаров, а также элементы фитопластики. Композиции из шаров самшита вечнозеленого разнообразит многолетник - госта подорожниковая. Рекомендовано часть парка реконструировать по типу регулярного планирования, а часть - по типу пейзажного.

Ключевые слова: парковые насаждения; генеральный план; баланс территории; цветники; дорожки; деревья.

V. P. Shlapak, A. V. Kodzhebash, I. V. Kozachenko, M. I. Parubok, S. A. Maslovata Uman National University of Horticulture, Uman, Ukraine

\section{ASSESSMENT OF CURRENT SITUATION OF THE PARK IN IVANIVKA VILLAGE OF UMAN DISTRICT AND THE PROJECT OF ITS RECONSTRUCTION}

Assortment of tree plantations in the Park of Ivanivka was studied. The analysis of the park plantations inventorying revealed that 316 trees and 5 bushes belonging to sixteen species and twelve families grow on the territory. Aesculus hippocastanum L., Acer platanoides L. and Tilia cordata Mill. were the dominant tree species. Phytosanitary state of many wood plants in the park was not satisfactory. Dry trees and trees with dry branches could be observed. Green plantations needed optimization. Paths system was not ramified. Small architectural forms were mostly absent. There was the only sculpture of T. Shevchenko, other sculptures were absent. There were benches only near the building. Reconstruction project of the park was made. It would be necessary to implement hollows conservation, sanitary cutting and chopping, etc. We recommend creating bush layer in phytocenotic structure using Berberis thunbergii D. C. 'Atropurpurea', Rosa robusta F. G, rard, Syringa vulgaris L., Forsythia suspense (Thunb.) Vahl, Laburnum anagyroides Medic. and other. Park needed to expand road-path system. There are rockeries with deciduous and coniferous bushes and different flowers in the project. Assortment of plants guaranteed decorative effect all year round. There are compositions of coniferous plants (Juniperus scopulorum 'Skyrocet', J. Sabina L. 'Tamariscifolia', J. horizontalis Moench 'Blue Chip', Thuja occibentalis L. 'Globosa' etc.) and single plants of Picea abies (L.) H. Karst. and Pinus sylvestrys L. in the project. We propose to install elements of public welfare as garden benches, summer house, lanterns and garbage bins. Mixborder with various flowers can be created around a summer house. Elements of topiary art - balls of Buxus sempervirens L., phytoplasty can be used in landscaping. Balls of $B$. sempervirens L. will be combined with Hosta plantaginea (Lam.) Asch. The project is characterized by regular and landscape park style.

Keywords: park plantations; general plan; balance of territory; flower beds; tracks; trees. 